\title{
IBN QAYYIM AL-JAUZIYYAH AND MARTIN LUTHER ON FAITH, RELIGION, AND SOCIAL RESPONSIBILITY IN TIMES OF EPIDEMIC/PANDEMIC: AN ISLAMO- CHRISTIAN PERSPECTIVE
}

\author{
Tyolumun Kinga-Upaa, SJ \\ Department of Political Science and Diplomacy \\ Veritas University Abuja, Nigeria
}

\section{Abstract}

In this article, I produce a comparative reading of ibn Qayyim al-Jauziyyah (1292-1350) and Martin Luther's (1483-1546) texts on protecting the healthy and caring for the sick in times of epidemics and pandemics. I point out the similarities between them and assert that, while both scholars did not explicitly argue for quarantine or physical isolation and social distancing as a religious duty, they did indeed lay a robust foundation for us to do so in the context of COVID-19, with new knowledge and technologies. In the first half of the $14^{\text {th }}$ century, the renowned medieval Islamic physician, jurisconsult and theologian from Damascus and student of Ahmad b. Taymiyyah (1263-1328), ibn Qayyim alJauziyyah, published Islamic guidance on the prevention of contagious diseases by enforcing physical social distancing and by means of quarantine in times of plagues in a manual of prophetic medicine "al-Tibb al-nabawi". The date of this publication is significant, as it corresponds to the time of the bubonic plague or black death that came from "the east" and spread all the way to Europe, killing between 25-30 million people. About two centuries later, Martin Luther, German professor of theology, composer, former priest and Augustinian monk, and a seminal figure in the Protestant Reformation, addressed the same subject from a Christian perspective. Replying to his former student, Johann Hess (1490-1547), who wrote asking for advice on whether the clergy might stay or flee a plague ravaging their city, Luther comes to a similar conclusion to ibn Qayyim alJauziyyah. Both scholars begin by trying to unite factions within their communities on the question of what was appropriate in the context of their religion. They then go ahead to outline practical measures for protecting the healthy and caring for the sick, with each rooting these in theological principles unique to his tradition.

Keywords: Interreligious dialogue; Christian/Muslim Studies; Epidemics; Pandemics; Sociology of Religion

\section{Introduction}

The study of the impact of lockdown and other physical social distancing measures that were introduced to curb the spread of the COVID-19 pandemic in many countries of the world, including some states of Nigeria, is just beginning. Yet, everyone feels the enormity of their social, economic, and psychological impact. With the suspension of 
public worship and all spiritual services requiring physical presence, religion was among the hardest hit aspects of our culture. Consequently, the emotional motivation that ritual participation affords religious adherents was lost together with the enormous support it gives to the mental health of societies with strong religious cultures. Although not always sufficiently trained, the clergy and religious institutions handle a significant amount of psychotherapy and most other counselling needs in environments such as sub-Saharan Africa, where this specialised care is grossly undervalued and underdeveloped. In this context, lockdown produced heightened stress levels, which in many instances exacerbated the problem of domestic violence and abuse that adequate spiritual support could have mitigated. Even at the official and administrative levels of religion, different degrees of tension were generated concerning the understanding of how to manage the imposition of lockdown and physical social distancing. Religious leaders and scholars theologians and jurists - attempted to give guidelines while pondering the immediate significance of these events for religious ritual and their consequences for the future. However, consideration is yet to be given to the elaboration of theological principles for explaining contemporary religious responses to the circumstances of COVID-19, especially for any religious leaders in doubt. To face up to this need, one must dig into history to recover and test for efficacy any means and methods that theologians and religious thinkers have used in the past to respond to similar circumstances.

To begin filling this gap, I do a comparative reading of the thoughts on plague epidemics and, by extension, pandemics of Shams al-Dīn Abū 'Abd Allāh Muhammad b. Abī Bakr b. Ayyūb al-Zur'ī al-Dimashqī al-Hanbalī (1292-1350), commonly known and henceforth referred to as ibn Qayyim al-Jauziyyah, renowned medieval Islamic theologian and physician from Damascus, and of Martin Luther (1483-1546), German professor of theology, composer, former priest and Augustinian monk, and a seminal figure in the Protestant Reformation. This is needed to offer a wider explanation to the issues of pandemics and tease out a theological position for our times. Comparing their social and theological treatment of plagues, epidemics and pandemics to our scientific and medical approach, I proceed to argue that they have left us grounds to declare physical isolation and social distancing an essential religious duty for both Christians and Muslims in the case of a pandemic such as COVID-19, with physical isolation and social distancing not being simply a matter of choice. This angle is important now when religious communities are faced with what could spiral into an existential crisis for them and their followers. Media pictures of empty churches and mosques and a YouTube video of a weeping imam in an empty Saudi Arabian mosque during a Friday prayer session at the start of the lockdown all raise the question of the whereabouts of God and whether he has been too silent or absent amid COVID-19 and its lockdowns. (For video of the emotional imam, go to https://www.youtube.com/watch?v=ZRdtZWdQbU0). With this I hope that the adherents of religions will in observing the imposed measures both now and in the future come to the consoling feeling that they were in deep worship of God through obedience to lockdown and rules of strict observance of quarantine and physical social distancing. 
Religion, intragroup tension, and division in times of plagues and epidemics: the $14^{\text {th }}-16^{\text {th }}$ centuries

During his career, the renowned Syrian medieval Islamic physician and theologian, ibn Qayyim al-Jauziyyah, found reason to reflect in a section of his manual of prophetic medicine "al-Tibb al-Nabaw $\vec{\imath}$ " on the prophet Muhammad's guidance on preventing contagious diseases through enforcing physical social distancing and quarantine in times of plagues. (For the English translation and relevant sections, see Abd El-Qader b. Abd El-Azeez 2003:178 - 186). There is no evidence in the text itself of what sparked his interest in this topic. However, following historical records, one might guess that the devastating $14^{\text {th }}$-century epidemic of bubonic plague, also known as the black death, is what most likely preoccupied his mind. This plague, which was subsequently declared a pandemic, entered Europe from "the east" around $1347 \mathrm{AD}$, ravaging the continent until about 1352. (Cohn and Tom:2020). It killed between 25-30 million people, and it took Europe roughly 200 years to recover (Cartwright:2020).

Ibn Qayyim al-Jauziyyah's text reveals the religious tension that the Islamic community knew during this and perhaps other plagues before it. Apparently, two factions emerged over the question of what the appropriate Muslim response might be with regard to the pestilence and its social effects. One group, quoting from a hadith of the prophet Muhammad, argued against the whole idea of lockdown, quarantine, social distancing, and fleeing from the place of pestilence. They made the case for staying back in the city and continuing to mingle with the sick, providing care and all the needed help as the appropriate Muslim response. According to ibn Qayyim al-Jauziyyah, "They brought as evidence what the Prophet Muhammad said: 'There is no contagion nor evil omen,' [citing this hadīth from both the Șahịh of imam al-Bukhārī and Muslim, and the Sunan of Abū Dawud]". (Abd El-Qader b. Abd El-Azeez 2003:180). If this point of view had prevailed, the implication would have been that public worship with large congregations during plague epidemics and pandemics would remain unaffected, even if it came at a huge human cost.

The second group also quoted from other hadiths of the Prophet to argue in favour of physical isolation, social distancing, and the wisdom of fleeing cities hit by pestilence as the faithful Islamic path. Ibn Qayyim al-Jauziyyah cites these reports:

Muslim [in the Șahīh] narrated that Jabir bin Abdullah said: "Thaqif”s delegation included a man with leprosy. The Prophet [Muhammad] sent to him, 'Go back, for we have accepted your pledge of allegiance'. Al-Bukhari [in the Sahīh h] narrated that the Prophet said: 'Do not keep looking at the person afflicted by leprosy'... [both narrators also report that] 'A healthy man should not be brought near a sick person"” (Abd El-Qader b. Abd El-Azeez 2003:178-179)

The obvious consequence from this position would be the suspension of public worship with large congregations for the sake of the safety of all and the preservation of life. It was this conflict brought about by both groups that the physician and theologian, ibn Qayyim al-Jauziyyah, set out to resolve in this section of his text on prophetic medicine.

Roughly 200 years after ibn Qayyim al-Jauziyyah's text, a similar scenario played out in a Christian context in Europe. A former student of Martin Luther's, who was subsequently a leader of the Reformation in Breslau (Wroclaw) - capital of Silesia, 
Johann Hess (1490-1547), wrote a letter on behalf of the evangelical pastors in Breslau, asking for advice on whether the clergy there might stay or flee the plague that was ravaging their city (Leroux 2007:225). In his reply, Martin Luther confronted the same conundrum that his Muslim counterpart dealt with two centuries earlier. The argument among the Christians also developed along two opposing lines: one faction held the firm position that a good Christian is obliged to remain in the area of pestilence and help those already afflicted, while the other took the position that one could properly flee, particularly if one held no public office. (For access to the letter go to https://www.academia.edu/42236069/). This apparent contradiction in prescribing methods for containing epidemics and curing plagues, as well as its attendant tension among professional and religious groups, was prevalent in ancient times. Wallis (2006:12) states and goes on to demonstrate that the debate on flight and the appropriate moral responsibility in times of plague epidemics was ongoing from the early modern period, but I would say that it stretches back even further as suggested by the text of ibn Qayyim al-Jauziyyah. That is why the attempt to find convergence for these enduring factions within divergent religious traditions by two scholars living two centuries apart is of immense significance even for our own context.

\section{Differences in the conception of plagues and epidemics}

Remarkably, Luther and ibn Qayyim al-Jauziyyah came to a similar conclusion despite enduring differences between their understanding of plagues and epidemics. Predictably, Luther follows the Christian belief of his time that plagues were a curse from God that brought about death to punish humanity for her sins (Luther 1527:1). Citing the scriptures, he emphasises that God has four scourges to accomplish this task: pestilence, famine, sword, and wild beasts (Luther 1527:3). The moral heroism which he advocates for both ministers of religion and public servants in times of plagues is rooted in this conviction, making the acceptance of any resulting death a spiritual obligation. The Muslim view as seen in ibn Qayyim al-Jauziyyah was, however, significantly different. While believing that sickness and diseases were permitted by Allah to have a certain effect on people, he does not consider plagues a curse, but rather as playing some salvific role as merciful gift of God which provides martyrdom to the faithful, whose souls are instantly transported to paradise (Mark:2020).

Another difference in opinion is Luther's notion that all epidemics, like any plague, are spread among people by the evil spirits, who poison the air or exhale a pestilential breath to put deadly poison into the flesh (Luther 1527:4). This attribution of plagues to supernatural causes was quite common in the $16^{\text {th }}$ and the $17^{\text {th }}$ centuries (McKeithen: Paragraph 1). Nonetheless, two centuries prior to Luther, ibn Qayyim al-Jauziyyah again viewed the causes of plagues from a more scientific perspective, almost going by today's standards. He thought that leprosy, tuberculosis, fever, and mange could be spread by mingling and sustained contact with odour from an infected person. In other words, there was something airborne about them. Conversely, as was in Luther's context, he did not attempt to distinguish between the spiritual and medical causes of diseases. This shows significant difference from our understanding of the causes of plagues and epidemics, which has been aided by scientific methods, that they are from either bacteria or viruses. Just as this scientific knowledge of causes has overtaken supernatural assumptions, we also have more precise methods for mitigating these agents and the effects of the 
diseases. Despite this, some leaders, still driven by religious passion and political motifs, have tended to argue against the science surrounding COVID-19. Pentecostal evangelicals, mostly in Nigeria and the US, criticised the closure of public religious worship. Sometimes, they would deny COVID-19 altogether and, at other times, argue for more fervent prayers, fasting, and worship as the most efficient means for curtailing the pandemic. Behind this attitude is that ancient Christian understanding of plagues as punitive from divine sources, spread through the agency of evil spirits, and requiring of repentance and prayers to overcome (Mark:2020).

Given the scepticism and factions developing around issues of the COVID-19 pandemic, one finds it fascinating how Luther and ibn Qayyim al-Jauziyyah tried to resolve a similar difficulty by integrating opposing views to create a safe path for responding to plagues and pandemics. If it is true that Luther was an opponent of flight as Wallis (2006:6) opines, then his reply to Johann Hess' letter marks a shift in position towards an inclusive and more conciliatory stance. This shift underlines the importance of compromise for building consensus in times of medical crisis. From this commonsense approach, which both scholars grounded in theology, we can draw guidelines from their texts and argue that, given our context, they would have maintained that quarantine and total lockdown of nations and cities, as well as physical social distancing, constituted religious and spiritual obligations in dealing with the current COVID-19 pandemic.

\section{Narrowing the divide and establishing the public health importance of unity}

The American President, Donald Trump, has increasingly politicised the novel coronavirus both internationally and domestically. Two of his favourite platforms for this have been the economy and religion. On the economy, his verbal attacks against China, which he has made the scapegoat for his government's dismal handling of the pandemic, keep escalating. One of Trump's extreme measures was the threat to withdraw all American funding for the World Health Organisation (WHO), which he has gone ahead to do, and worse still pulled the USA out of the WHO. To accomplish this, he unilaterally indicted the $\mathrm{WHO}$, for allegedly submitting itself to China's ploy to establish itself as the world's economic superpower. This has been one of his many conspiracy theories around COVID-19. On the domestic front, Mr. Trump continues to accuse governors, mostly of states run by democrats, of sabotaging his republican administration with their insistence on strict observance of lockdown and other scientific protocols for checkmating the pandemic. He claims that their adherence to the science of the pandemic was done to weaken the economy, in which he takes prides as the strongest point of his pre-Covid-19 administration in an election year. But when even that did not appear to work for him, he made the religious argument, going as far as ordering that places of worship be opened so that believers could return to full religious participation. In this argument, he made the lockdown look like secularists' satanic attack on religion driven by the democrats. Trump's approach to COVID-19 has far reaching consequences for many countries of the so-called global south, especially in Africa where whole nations look to America for leadership and still believe in her presumed infallibility.

In his response to Donald Trump's attack on the WHO, the organisation's Director General, Tedros Ghebreyesus, forcefully underlined unity as a sine qua non for any successful fight against epidemics and pandemics: 
COVID-19 does not discriminate between rich nations and poor, large nations and small. It does not discriminate between nationalities, ethnicities or ideologies. Neither do we. This is a time for all of us to be united in our common struggle against a common threat - a dangerous enemy. When we are divided, the virus exploits the cracks between us (WHO's Director-General's opening remarks at the media briefing on COVID-19, 15 April 2020).

Today as always, this message remains pertinent not just for our politically and economically globalised world but also for all local communities and religious leaders in times of epidemic and pandemic. This is what was being suggested at different times by these two influential scholars and religious leaders of the medieval and early modern periods as their communities struggled with plagues. The purpose of unity was not only to establish singularity of purpose but also to help in building an environment and conditions that strengthened the mental health of the population. Both scholars believed that fear and anxiety weakened the immune system and so were detrimental to public health at times of such crises. Martin Luther even proposes a prayer against fear at such times (Luther 1527:4-5). Consequently, his letter to Johann Hess expresses a strong preference for the opinion that one need not and should not run away from a deadly plague, but even then, without condemning those who pushed the notion that one could flee from the danger of a pestilence in the city. One of the major objectives of the letter is to narrow the divide within the Christian community. This same approach had been used by ibn Qayyim al-Jauziyyah two centuries earlier when the Muslim community was under the threat of the black death pandemic. Both scholars therefore find theological grounds within their religious traditions to achieve the required unity and moral responsibility needed for combatting the scourge of pestilence while maintaining social and religious cohesion.

\section{Two Traditions, Same Vision}

Despite religious divergence, both authors advance a theological argument built on the notion of obedience to God, spiritual bravery, and religious charity to merge two conflicting views that threatened the faith and safety of two religious communities with a major rift. Standing before suffering and death at the time of a pandemic, Luther begins by taking up the theological argument from the bible that both were God's punishment upon humanity for committing sin (See Gn.3). Consequently, the Christian was under obligation to submit to death when it became necessary, especially for a greater cause such as charity in the case of the scourge of pestilence (Luther 1527:1). Furthermore, such heroism is recognised as a sign of fidelity and a strong expression of the Christian's belief in God's omnipotence, which saves those with strong faith from the evil of sickness, pain, and death. Latent in this is the belief that, if one caught the disease and even died, then it was God's will that that should happen. To run away from pestilence and abandon the city's sick and vulnerable could therefore be a sign of disbelief and weakness of faith (Luther 1527:1).

With the foregoing, one would expect an explicit condemnation of weak faith and disbelief, but that is not what happens. Luther does not condemn those who argued for physical isolation and social distancing as expressed in the call to flee the city of 
pestilence but uses the Pauline teaching that faith could legitimately be weak and strong to exonerate them:

...it is generally true of Christians that few are strong and many are weak, one simply cannot place the same burden upon everyone. A person who has a strong faith can drink poison and suffer no harm, Mark 16 [:18], while one who has a weak faith would thereby drink to his death .... Christ does not want his weak ones to be abandoned, as St. Paul teaches in Romans 15 [:1] and 1 Corinthians 12 [:22 ff.] (Luther 1527:1)

According to ibn Qayyim al-Jauziyyah, a section of the Ummah (community) had already framed the question in the form of direct accusation against the Sunnah (prophetic tradition) as self-contradictory were both positions to stand. According to them, the only way out of this conflict was to rely on the Islamic hermeneutical principle of naskh (abrogation) to invalidate one of the positions. However, ibn Qayyim alJauziyyah exploits the ambiguities in the same principle to find a theological basis for maintaining that both positions were valid. Simply put, the doctrine of abrogation stipulates that, when two obviously contradictory positions are found in Islamic scriptural or prophetic traditions, the latter supersedes the former by abrogation (for a quick understanding of this principle and the issues contained within it, see Yusuf Suiçmez 2012). The foundations of this doctrine come from the Qur'ān itself as it states thus:

We do not abrogate a verse or cause it to be forgotten except that We bring forth [one] better than it or similar to it. Do you not know that Allah is over all things competent? .... And when We substitute a verse in place of a verse - and Allah is most knowing of what He sends down - they say, 'You, [O Muhammad], are but an inventor [of lies]'. But most of them do not know (Q. 2:106; 16:101).

However, the application of abrogation to the Qur'ān and the Sunnah is restricted to one period only - the lifetime of the Prophet (Yusuf Suiçmez, 2012:34). Despite being considered authentic hadiths of the Prophet, ibn Qayyim al-Jauziyyah circumvents this doctrine in dealing with their obvious contradiction, thereby admitting the validity of all of them.

In arguing for fleeing the pestilence, one group cites the set of purportedly authentic hadìths reported in Islam's two most trusted sources of traditions (al-Bukhārī \& Muslim) already quoted above. At the same time, the second group also argues for staying with the sick by bringing as evidence what the prophet Muhammad has equally been quoted as saying in both al-Bukhārī \& Muslim, "There is no contagion nor evil omen" (Abd ElQader b. Abd El-Azeez 2003:180). Notwithstanding this overt contradiction, ibn Qayyim al-Jauziyyah begins with the categorical statement, "We say that there is no contradiction, because each statement has its own meaning and time frame" (Abd ElQader b. Abd El-Azeez 2003:181). The purpose of this was to bring back and maintain unity, which he considered the condition sine qua non for defeating pestilence.

To reinforce the notion of contextual meaning to accommodate the two statements of the Prophet and support his position against the accusation of contradiction, ibn Qayyim 
al-Jauziyyah also admitted the reality of weak and strong faith in Islam. I find a convergence here between him, St. Paul, and Martin Luther. This argument furnished him with the support for the Prophet's statement that "There is no contagion nor evil omen". According to him, the Prophet says this because some people have such strong faith and reliance on Allah that the strength of their faith would save them from contagious diseases, while others, not having such strong faith, are meant to adopt caution and rely on the hadìths emphasising contagion (Abd El-Qader b. Abd El-Azeez 2003:183). Martin Luther later writes as already quoted above that strong faith can save from poison where weak faith might lead to death (Luther 1527:1). Both writers implicitly laud those who are strong in faith for showing a heroic example while still not condemning the weak but insisting that they too were not wrong. Ibn Qayyim alJauziyyah defends the authenticity of this attitude by saying that, "The Prophet, who was full of mercy and pity for his nation, commanded them not to expose themselves to what might bring harm to their bodies and hearts" (Abd El-Qader b. Abd El-Azeez 2003:179).

To make a strong case for those who may choose to flee death in the case of a plague, Martin Luther explains that such a choice is not wrong in itself as examples of it abound in the patriarchal narratives, the books of Kings and of the prophets in the Old Testament, beginning from Abraham. Anticipating the possible response and contention from those who might disagree with this position by emphatically stating, "but these examples do not refer to dying by pestilence but to death under persecution", he simply answers, "Death is death, no matter how it occurs. According to Holy Scripture God sent his four scourges: pestilence, famine, sword, and wild beasts. If it is permissible to flee from one or the other in clear conscience, why not from all four?" (Luther 1527:3). Ibn Qayyim al-Jauziyyah on his part gives the example of the prophet Muhammad:

The Prophet implemented his own commands in both cases, so that the strong imitate his acts, depending on their trust in Allah. On the other hand, the weak would imitate the Prophet [as when he avoided the sick with contagion] in being cautious. Both ways are correct, but one is suitable for those who have strong faith while the other is suitable for those who have weak faith. Consequently, both groups of the believers will have their own method that is suitable for their own situation (Abd El-Qader b. Abd El-Azeez 2003:183 - 184).

This attitude was necessary to provide the theoretical foundations for the safety and preservation of the life of the community and at the same time to charitably respond to the needs of the vulnerable, the sick, and the dying. Once the first objective was met, both thinkers turned their attention to generating protocols for the safety of the community and laid down the conditions for fleeing a city under plague and how one might stay behind and in contact with the sick and needy to help them.

\section{A practical theology of safety}

For dealing with plagues, ibn Qayyim al-Jauziyyah simply cites the Prophet's command that "If it appears in a land where you are residing, do not depart that land. If it appears in a land, do not enter it" (Abd El-Qader b. Abd El-Azeez 2003:183). In explaining the first part of this command, he says that it was given because the Prophet did not want members of his community to allow themselves to go through the temptation of thinking 
that by fleeing, they might be able to avoid Allah's appointed destiny of death. This would amount to insubordination and the refusal to surrender to the will of Allah, which is the essence of Islam. For the second part, which orders them not to enter a city of plague, he says that it was because he wanted to teach them that "remaining in the healthy land brings calmness to the heart and tranquillity in their livelihood" (Abd El-Qader b. Abd El-Azeez 2003:183). As Allah demands total submission of Muslims, he also wants them to be protected and to provide for one another and stay happy. That means that the first part of this order is essentially intended to strictly isolate affected cities so as to curb the spread of the plague, then attempt to find a cure for the sick and protect the life of those not yet infected. The prophetic injunction is a command from Islam's holiest source for individuals and cities to quarantine and practice lockdown, and it perfectly matches the objective of maintaining calmness and tranquillity in both places touched and untouched by the plague.

Much as the Prophet wants the healthy to keep away from harm so that they may not worsen the situation by constituting a key source of the spread of the disease, he still places upon those already in the affected cities and whose families, relations, neighbours, and friends were already afflicted the social responsibility of supporting their sick, even of eating with them while still observing the prescribed caution. That is why he is reported in one hadith to have eaten with a leper. Ibn Qayyim al-Jauziyyah explains that it was for the purpose of calmness and tranquillity and to show unbridled trust in Allah through such acts of charitable love that the Prophet says, "there is no contagion or evil omen" (Abd El-Qader b. Abd El-Azeez 2003:183).

Nevertheless, ibn Qayyim al-Jauziyyah was also aware that mixing care and charitable love with public religious rituals and other spiritual obligations for persons untrained in dealing with plagues was too risky. That is why he fell back on the second category of sayings from the Prophet's Sunnah about avoiding contagious diseases and emphasised two types of contagion. The first contagion is like the one we get from leprosy and tuberculosis, which can be a constant reality in any community and could be lived with without the threat of decimation of life (Abd El-Qader b. Abd El-Azeez 2003:178 - 182). The second type of contagion comes as pestilence, which is sudden but can last for a period with the capacity to wipe out an entire population (Abd El-Qader b. Abd El-Azeez 2003:183). Ibn Qayyim al-Jauziyyah therefore uses the common situation of leprosy and tuberculosis to help the community understand how to apply caution and survive pestilential epidemics. According to him, this was exactly what the Prophet intended to teach where he is quoted to have promoted quarantine and social distancing in the hadiths on Thaqif's delegation comprising of a leper, avoidance of prolonged gaze at a leprous person, and on bringing a healthy person near the sick (Abd El-Qader b. Abd El-Azeez 2003:178 - 179). In ibn Qayyim al-Jauziyyah's presentation, the Prophet is emphatic about the safety and protection of the community. This constitutes the rule, and the only condition for relaxing it was to ensure the care and charitable support of the sick. That is why ibn Qayyim al-Jauziyyah concludes that, "As for short visitations with such people for a good purpose, there is no harm in it and catching the disease will not be plausible during these brief contacts", and, one might add, with appropriate caution (Abd El-Qader b. Abd El-Azeez 2003:184).

Most of the practical measures suggested by ibn Qayyim al-Jauziyyah in his text are consistent with our safety protocols for combatting COVID-19. While it was important 
to emphasise charitable help for the vulnerable, the sick, and the dying, as well as of burying the dead, he also recognises that certain bodies were prone to disease and could easily be infected just by being around already affected people and their surroundings. That means that any large gatherings of people for whatever reason, including worship and burial, were dangerous and to be prohibited during a pandemic. He also taught that sometimes even the fear of disease could actually weaken the immune system of certain bodies making them susceptible to it, as one catches certain diseases just by smelling the foul odour emitted by persons afflicted by them (Abd El-Qader b. Abd El-Azeez 2003:179-180).

In ibn Qayyim al-Jauziyyah's time, it was thought that one could become contaminated and infected with leprosy from the odour that is emitted from persons already afflicted by it. This was the same case with tuberculosis, hectic fever, and mange (a skin disease of mammals caused by parasitic mites). Therefore, like COVID-19, those who talked and sat near a leper or those afflicted with these other ailments for a long time were prone to falling victim to them. For that reason, doctors ordered that the healthy were not to be exposed for long periods to those suffering from these conditions to avoid being infected. That medical advice laid further credence to what the Prophet is reported to have commanded, "No sick person should be brought near a healthy person" (Abd El-Qader b. Abd El-Azeez 2003:181 - 182). It was thus that in aiming for unity to combat pestilence in the community by protecting citizens and guaranteeing the care of victims ibn Qayyim al-Jauziyyah found it necessary to sidestep the Islamic hermeneutical principle of abrogation. He emphasises contextual meaning and argues that two contradictory positions could be meaningfully and validly embraced by the Prophet depending on the place, time, and situation.

Almost two hundred years after ibn Qayyim al-Jauziyyah's text, Martin Luther identified two categories of people he considered duty-bound to stay and not flee a pestilence. These frontline staff include those engaged in spiritual ministry, such as preachers and pastors, who he says must remain steadfast even before the peril of death because of the command from Christ that a good shepherd lays down his life for the sheep. Only the hireling flees the wolf, abandoning the sheep (Jn.10:11). The task of these ministers was mainly to accompany the dying, strengthening, and comforting them by word and sacrament so that in faith they might overcome death (Luther 1527:2). As much as this required physical presence then, and may still do today in varying degrees despite the advent of the Internet and social media, this contact with religious ministers is by no means intended to keep churches open and encourage large gatherings of congregants at prayer for the miraculous disappearance of the epidemic. For Luther, the religious obligation at such times is to attend to the sick and the dying, possibly turning churches, parish halls, rectories and presbyteries, or any other form of residence for religious ministers into places for housing and caring for the sick. Applying this to COVID-19 would therefore have meant turning our parishes or church halls into isolation and treatment centres, especially in the developing world where resources are so scarce that even test kits have been in short supply. Utilising the massive structures used for religious gathering for isolation space could have freed up resources for kits and other medical supplies. This would have made perfect collaboration between church and state, which should still have its place even today. 
The second group under obligation to remain consists of those in public service charged with the responsibility of organising and protecting cities, such as government appointed public health workers and their support staff, administrators, judges, and security personnel. From his understanding, this was in keeping with God's commands which instituted secular authority to rule, protect, and preserve life and the city. As St. Paul teaches in Rm.13:4, these are God's ministers for our own good. For these to abandon the city of plague would be tantamount to great sin on their part (Luther 1527:2). For our time, we could include groceries' suppliers and food vendors among the frontline staff.

Martin Luther further emphasises that even those persons and groups not under spiritual and social obligation to stay had a moral duty towards their neighbours and could only flee if they had made adequate arrangements to cater for the needs of the weak, the sick, and the dying. All who are in the relationship of parentage, mutual service, and neighbourliness are not to leave without making adequate arrangements for care of one another. "No one should dare leave his neighbour unless there are others who will take care of the sick in their stead and nurse them" (Luther 1527:2). From this injunction, one can emphasise the call to volunteering for the sake of the vulnerable in society as the fundamental mission for religious and their institutions. However, in circumstances where enough spiritual ministers, public health workers, administrators, judges, and security personnel, as well as other volunteers, are already available and adequately discharging these roles, others can leave in order not to needlessly expose themselves to danger. Martin Luther cites the example of St. Athanasius, who fled his church to spare his life because many others were already there to administer his office, and that of St. Paul, who escaped from Damascus, lowered in a basket over the wall as recorded in Acts 9:25 and Acts 19:30 as supporting of this rule.

A similar assertion to that of the hadith of the prophet Muhammad; ordering that, if a plague appeared in the land of your residence, you were not to depart it; and that, if it did in a land where you were not resident, then you were not to enter it, is made by Martin Luther. He says, "if a deadly epidemic strikes, we should stay where we are, make preparations and take courage in the fact that we are mutually bound together so that we cannot desert one another or flee from one another" (Luther 1527:4). However, only when the vulnerable, the sick, and the dying have been sufficiently cared for should those who are well escape to safety. The overarching principle for both scholars is therefore to show love and care for the neighbour and to preserve human life.

\section{Physical isolation and social distancing as religious duties against pestilence and pandemics}

This interpretation of religious doctrine is influenced to some degree by the social ethos of the environment in which it is practiced. This is why there have been divergent reactions to the lockdown and social distancing measures that have been imposed to curb the spread of the coronavirus, especially as they have affected the economy and the predominant religious cultures of nations and societies. At the beginning of the COVID19 anxiety, religious leaders in most European countries, the UK, and the USA accepted the closure of churches and mosques to implement social distancing. Even in Saudi Arabia and the Vatican, these safety measures were accepted in good faith by religious 
enthusiasts and their clerics. However, the story has not been the same in parts of Africa, especially Nigeria, and yet both measures can and have been defended theologically.

On 19 March 2020, Lagos state, which recorded Nigeria's index case, took up its leadership role in the fight against the COVID-19 pandemic by announcing the closure of all schools and markets with the exception of those selling food items. This came into effect on Monday, 23 March 2020. Alongside this was also the prohibition of any religious gatherings with a crowd of more than 50 congregants. Soon after, there was an announcement of similar measures by all seven north-western states of Nigeria and at least two in central Nigeria. Despite this, the police still struggled to implement social distancing. In some cases, they had to use forcible means to stop public worship in major churches across these areas on Sunday, 29 March 2020. Several Christian and Muslim clerics were still vehemently opposed to this and had to be forced out of their churches and mosques. In Kano and Katsina states, riots even broke out against the prohibition of Friday mosque attendance, resulting in arson against some police stations. Those responsible for this act were a group of clerics standing against the safety measures of physical social distancing simply because they affected religious activities (Nigerian Vanguard, 29 March 2020). The consequences of this insubordination came in the form of the dire COVID-19 situation that has been experienced in Kano, giving room for rumours of mass deaths (Tijjani, A. INDEPENDENT [Nigerian Newspaper], 20 April 20; Oyelere-Kano, K. Nigerian Tribune, 20 April 20).

For economic and political reasons more than health and safety, governments around the world are either opening or partially easing lockdowns. This has introduced another complexity into the religious conversation. As the British Prime Minister, Boris Johnson, prepared to announce measures for easing the COVID-19 lockdown in the UK, the Bishops of the Church of England reiterated their support for the government's plans for reopening (Sarmiento 2020). An imam of the Muslim community also called for mosques not to reopen before the end of Ramadan because of the unique setup of ritual and prayer in mosques. However, even within the Anglican communion in England, vibrant internal church squabbling about the lockdown reverberated amongst the bishops. A faction blamed the church's leadership for acting far beyond government protocols and essentially hurting spiritual life, with their clergy rallying revolt against official church lockdown (Sarmiento 2020). Elsewhere, as the Italian government agreed with its Bishops' Conference and was preparing to reopen churches for worship on 18 May 2020, a minority group of cardinals spearheaded a petition; signed mostly by Italian clergy, academics and journalists; referring to the "COVID-19 lockdowns as an assault on religious liberty, a threat to the global economy and a conspiracy to separate families" (The Associated Press:2020).

Nigeria's Pentecostal mega pastors also argued about the implicit infidelity to the faith of church leaders who were accepting of governments' social distancing protocols that closed churches even before cities were locked down. This sentiment is shared by quite a number of clergy across Christian denominations. Bishop David Oyedepo of Living Faith Church criticises the government for closing churches but opening markets, which, according to him, are rowdier and incapable of observing social distancing. The President of the LoveWorld Incorporated or Christ Embassy, Pastor Chris Oyakhilome, had earlier slammed church leaders who agreed to the lockdown of churches without praying and consulting with other pastors (Folarin:2020). In this scenario, we see that 
the problem of divided opinion, which plagued the Muslim and Christian communities of the $14^{\text {th }}$ and $16^{\text {th }}$ centuries, as seen in the publication of ibn Qayyim al-Jauziyyah and the letter of Martin Luther, has returned and is very much alive in our time, further threatening the unity that is needed at such a crucial moment.

The two thinkers that we have been reading do not explicitly declare social distancing a religious duty, but this may have been because of huge cultural constraints that our context has since removed with the advent of the Internet and smart gadgets, satellite television, better water hygiene, and scientific advancements that have afforded us an excellent, quicker, and more responsive medical culture. Therefore, we cannot just focus on the guidelines that they provided for communities in their peculiar context, but most go even deeper in search of the spirit behind them to see what they would say in our circumstances.

As we have seen during the COVID-19 lockdown, the Internet, computers, tablets, and smartphones allowed all modes of social bonding and closeness that were only possible by physical contact before their advent. Churches and mosques streamed services and programmes. Technology has improved our capacity for care and even specialised it as we have seen in the management of COVID-19. Soon our robotic culture may provide ways of helping the vulnerable and sick that will remove most of the direct human need for it. Furthermore, with well-trained and adequately positioned public health officials and civil authorities appointed by God for administering our societies, and with the technological advancement of our age, the need for ordinary believers to go out and answer some of the call to care for the sick is being met at a higher degree of efficiency. The most pertinent thing is to ensure the protection of life, mostly of those not exposed. There is an emerging theology around social media and its impact on faith. And, even if its ritual and sacramental value are still very limited as some have contended (Grayland:2020), social media apps have made possible some form of spiritual ministry of attending to the gravely sick and dying by web counselling. These apps have served to connect, inform, and encourage people during the COVID-19 lockdown. Therefore, in our age, one cannot just speak of social distancing in a world governed by virtual reality. That will be too vague. We are always socially connected, even when physically distant. It is perhaps more accurate to qualify the social distancing with "physical", which entails the removal of social connectedness through close physical proximity.

The surprise element in COVID-19 left everyone unprepared, but it is important to prepare people ahead of such sweeping changes regarding how they relate to their spiritual life. It was easier for Muslims and Pentecostal evangelicals to adapt because of their worship format. Their structure had already prepared them to operate in small groups. No matter how small the group composition, even at the level of family, Muslim and Pentecostal prayer gatherings have a legitimate imam and pastor to ensure the plenitude of their worship. The Catholic and other sacramental denominations were hit hardest. Data is emerging from families about their lockdown experience, and it seems that the Internet could not assure sufficient sacramental experience. Only one sacrament was practiced but not fully, for even the virtual Mass is problematic (Grayland:2020). All other sacraments stopped. This is where the Church could have been more creative and the Priests heroic by making right judgements and going into places with relatively low risk to meet those in fear and hungry for the sacraments. Both ibn Qayyim alJauziyyah and Martin Luther give room for this for both religious traditions where 
necessary, and so priests and ministers of religion can obtain the status of frontline workers, giving them permission to visit families. There was no reason for private celebration of the eucharist and other sacraments with families in their homes and in the basic Christian communities not to have continued, especially with the ministers trained in observing all the safety protocols. With this, there would be no need for premature clamouring to return to public religious worship before the virus' total disappearance.

Before proceeding, I would like to state categorically that my overall argument is to analyse churches' and mosques' initial stance on social distancing and lockdown of religion alongside the economy at the time of the heightened health danger of a pandemic. The idea is to find out what the right attitude is supposed to be, giving due consideration to social and moral responsibility and religious obligation. It would seem appropriate to look for a universal principle here for places of religious worship wherever they may be at such a time of pandemic. However, when it came to relaxing the lockdown and strict measures for social distancing, individual communities and nations could vary depending on the organisational structures of each. In this regard, Europe, the UK, and USA, with comparatively better organised systems of public transportation and shopping, may find places of public worship more challenging and most dangerous to reopen at the outset of the easing of measures. The same cannot be said of sub-Saharan Africa, especially Nigeria. The organisational structure of this society is such that easing lockdown and allowing movement by public transportation already rubbishes any idea of social distancing. Therefore, it can be rightly said to be hypocritical not to allow churches that are more organised than the market setting to reopen. What remains challenging is the question of whether religious groups and institutions should be looking at reality in a pandemic from the prism of economic survival and social advantage. Should they not rather have been engaging civil leadership more on finding measures that assured long term protection of life and the general welfare of society?

In the context of the medieval and early modern periods, these religious scholars identified two major roles for religion in a pandemic. These were the protection of the healthy population and care of the vulnerable and sick. For the protection of the healthy, ibn Qayyim al-Jauziyyah's idea is inspired by the Prophet's injunction that there should be a lockdown as he ordered that "If it appears in a land where you are residing, do not depart that land. If it appears in a land, do not enter it" (Abd El-Qader b. Abd El-Azeez 2003:183). Luther also towed the same line, stating that "if a deadly epidemic strikes, we should stay where we are, make preparations and take courage in the fact that we are mutually bound together so that we cannot desert one another or flee from one another" (Luther 1527:4). Both positions will serve to cut the chain of spread and help organise care and cure. This teaching provides a suitable theological foundation for either total or partial lockdown of a nation, especially around the affected areas. In the case of COVID19, both Christians and Muslims owed it to one another, to the nation, and indeed to the entire world to embrace the lockdown with the confidence required of us whenever we keep other religious obligations. Under strict conditions, the fearful or weak of faith could leave the city but only if they were sure that they were not already carrying the disease themselves. All this is done under the obligation to protect life and help stop the spread of sickness and death, which were understood to have their source in the devil and his evil spirits (Luther 1527:4). For Luther, to participate in the spread of contagious disease is therefore to be in aid of the devil. Our understanding of these realities is totally 
different today, but we still know that pain and suffering, especially from sickness and death, carry with them an element of evil that gravely hurts the human person and even entire communities. This is why Christians and Muslims must recognise this obligation to stop the spread of such evil as a religious duty.

Furthermore, once stopping the migration of the disease was ensured, the next step would be to ensure that the vulnerable and sick were cared for in the lockdown. For this to happen with great love and charity, ibn Qayyim al-Jauziyyah emphasises the need for strong faith and belief in Allah, from which the Prophet taught that there was no contagion and evil omen. This means that, whatever the outcome, it is to be understood as responding to Allah's decree for the believer. Armed with this belief, the healthy and strong who stayed in the city were under obligation to nurse the sick and support the vulnerable. However, he insists on quarantining the sick and observing social distancing in the process. This is where he employs the Prophet's commands that contagion be kept at arm's length and their sick not brought near a healthy person. He only permits short visitations with the sick for good purposes. This follows the understanding of the time that diseases such as leprosy and tuberculosis and many other contagions spread through constant and long inhalation of odour from those who carried them. Those who sat near a leper or persons carrying the other contagious diseases and talked for long periods were prone to falling sick with them. This is indeed what is thought of COVID-19, and so quarantine and social distancing also apply here.

Luther, for his part, goes so far as to declare that those who grew fearful and fled the city without arranging for the care of the sick were falling into grave sin. This is what he called "the sin on the left hand". However, those who stayed back could also fall into another sin which he called "the sin on the right hand" (Luther 1527:6). This means that you stayed back in the city but became rash and reckless, disregarding every precaution that counteracted the spread of sickness and death from the pestilence. According to him:

They [are those who] disdain the use of medicines; they do not avoid places and persons infected by the plague, but light-heartedly make sport of it and wish to prove how independent they are. They say that it is God's punishment; if he wants to protect them, he can do so without medicines or our carefulness. This is not trusting God but tempting him (Luther 1527:4).

This situation was repeatedly met, and this view was strongly expressed by many religious enthusiasts during the 2014 Ebola virus epidemic in West Africa, and it has been loudly re-echoed in this pandemic. The theology has been less of death as punishment but of God as an all-powerful being who will never leave his faithful afflicted with large-scale sickness and death irrespective of the recommended health and safety protocols. With this attitude goes the argument that religious observances and public gatherings in churches and mosques should have been allowed to continue. However, this is exactly what ibn Qayyim al-Jauziyyah says that the Prophet refused, and Martin Luther agrees with him. They both argue for quarantine and physical social distancing to protect human life and its dignity and sanctity.

The time of pandemic is a time of uncertainty. So, much as one understands our religious energy and enthusiasm, we ought to accept the protective measures established by competent authorities until we are certain that the worst days are behind us. In doing 
this, both Christians and Muslims will be following in the footsteps of their ultimate leaders. As ibn Qayyim al-Jauziyyah points out, the Prophet was always full of mercy and compassion for his ummah and striving to keep them away from whatever might bring harm to their bodies and hearts (Abd El-Qader b. Abd El-Azeez 2003:179). For the Christians, Jesus was also the protector and calmer of his flock. As the good shepherd, he tended and healed their wounds and other infirmities. As we have seen in the two texts, to accomplish the task of facing such dangers as come with plagues and pandemics sometimes requires that consideration for unity overrides many other concerns, and the principle of contextual meaning becomes the hub of theology and spiritual and religious interpretation. But these must always be pursued in the spirit of sincerity and trust. Therefore, churches and mosques across the world who adhered to the safety protocols of lockdown and physical social distancing were not only right to do so but actually observing a religious duty of the highest order.

\section{BIBLIOGRAPHY}

Al-Jazeera. Online: https://www.aljazeera.com/news/.

$B B C$. Online: https://www.bbc.com/news/world_radio_and_tv.BBC.

Cartwright, M. 2020. Black death. Ancient History Encyclopedia. [Online]. Available

at: https://www.ancient.eu/Black_Death/ (Accessed: 21 April 2020).

$C B C$. [Online]. Available at: https://www.cbc.ca/news/world/catholic-churchcoronavirus-petition-1.5561073 (Accessed: 14 May 2020).

Channels television. [Online]. Available at: https://www.channelstv.com.

CNN international. [Online]. Available at: https://edition.cnn.com/world.

Cohn, S. and James, T. B. 2020. Black death facts: your guide to "the worst catastrophe in recorded history". History Extra. Online: www.historyextra.com (Accessed: 21 April 2020).

Folarin, S. Opening markets, closing churches for COVID-19 wrong -Oyedepo. Punch [Nigeria] Newspaper. [Online]. Available at: https://punchng.com/openingmarkets-closing-churches-for-covid-19-wrong-oyedepo/.

https://punchng.com/oyakhilome-knocks-christian-leaders-for-supporting-churchclosure/ (Accessed: 7 May 2020).

Grayland, J. P. 6 May 2020. Opening the liturgical debate: is virtual Mass here to stay? And what does it say about the depth of the post-Vatican II liturgical reform? La Croix international. [Online]. Available at: https://international.lacroix.com/news/opening-the-liturgical-debate/12319?campaname=_May11 (Accessed: 11 May 2020).

Ibn al-Hajjāj, Abū al-Husayn Muslim (d. 875 AD). Șahīh Muslim. Edited and translated by Muhammad Muhsin Khan. 2007. Riyadh-Saudi Arabia: Darussalam publishers and distributors.

Ibn al-Ash'ath, Abū Dāwūd Sulaymān (d. 889 AD). Sunan Abī Dāwūd. Edited by Abū Tāhir Zubair 'Alī Za'I. 2008. Riyadh-Saudi Arabia: Darussalam publishers and distributors. 
Ibn Ibrāhīm al-Bukhārī, Abū 'Abd Allāh Muḥammad b. Ismā'īl (810-870 AD). Saḥ̄ịh al-Bukhārī. Edited and translated by Muḥammad Muhsin Khan. 1997. RiyadhSaudi Arabia: Darussalam publishers and distributors.

Ibn Qayyim al-Jauziyyah (1392-1350 AD). al-Tibb al-Nabawī. Translated under the title: Healing with the medicine of the Prophet by Abd El-Qader b. Abd El-Azeez. 2003. al-Mansoura, Egypt: Dar al-Ghadd al-Jadid.

Independent [Nigeria Newspaper]. [Online]. Available at: https://www.independent.ng/breaking-covid-19-kano-dismisses-rumour-of-massdeath/ (Accessed: 20 April 2020).

Leroux, N. R. 2007. Martin Luther as comforter: writings on death. Leiden|Boston: Brill.

Lucky, J. 2020. To quarantine is Christian: an act of service. La Croix international. [Online]. Available at: https://international.la-croix.com/news/to-quarantine-ischristian/12071?campaname=_30Mar (Accessed: 30 March 2020).

Luther, M. (1483-1546 AD). Whether one may flee from a deadly plague. [Online]. Available at:

https://www.academia.edu/42236069/Whether_One_May_Flee_From_A_Deadly _Plague (Accessed: 16 March 2020).

Mark, J. Religious response to the black death. Published in Ancient History Encyclopedia. [Online]. Available at: https://www.ancient.eu/article/1541/religious-responses-to-the-black-death/. (Accessed: 07 September 2020).

McKeithen, A. Advices for preventing and curing plagues in sixteenth and seventeenth century England. Published in The Plague Book, University of Virginia historical collections at the Claude Moore health sciences library. [Online]. Available at: http://historical.hsl.virginia.edu/plague/mckeithen2.cfm.html. (Accessed: 03 September 2020).

Nigeria Television Authority (NTA). [Online]. Available at: https://www.nta.ng. Nigerian Tribune. [Online]. Available at: https://ribuneonlineng.com/report-of-massdeaths-in-kano-untrue-govt/ (Published: 20 April 2020).

Nigeria Vanguard Newspaper. [Online]. Available at: https://www.vanguardngr.com/2020/03/covid-19-one-dies-90-arrested-in-katsinafor-burning-police-station/ (Published: 29 March 2020).

Sarmiento, S. Churches respond to government recovery strategy; Church access: responses to criticism of the bishops, Thinking Anglicans. [Online]. Available at: https://www.thinkinganglicans.org.uk (Accessed: 13 May 2020).

Suiçmez, Y. January 2012. Abrogation in hadith. ResearchGate. [Online]. Available at: https://www.researchgate.net/publication/268506778 Jan. 2012 (Accessed: 6 May 2020).

Theilmann, J. and Cate, Frances. 2007. A plague of plagues: the problem of plague diagnosis in medieval England. The Journal of Interdisciplinary History (published by MIT Press), 37(3):371-393.

The new Oxford annotated Bible. Edited by Michael D. Coogan, et al. Fifth edition.

The Nation [Nigerian Newspaper]. Online: https://thenationonlineng.net/kano-policearrest-15-imams-for-defying-lockdown-order/ (Published: 22 April 2020). 
The Qur'ān. As translated into English by Șahīh International. [Online]. Available at: https://asimiqbal2nd.files.wordpress.com/2009/06/quran-sahih-international.pdf. (Accessed: 17 April 2020).

Wallis, P. February 2006. Plagues, morality and the place of medicine in early modern England. The English Historical Review (published by Oxford University Press), February 2006, Vol. 121, No. 490.

WHO Director-General's opening remarks at the media briefing on COVID-19 - 15 April 2020. [Online]. Available at: https://www.who.int/dg/speeches/detail/whodirector-general-s-opening-remarks-at-the-media-briefing-on-covid-19---15-april2020 (Accessed: 14 May 2020).

YouTube. [Online]. Available at: https://www.youtube.com/watch?v=ZRdtZWdQbU0 (Accessed: 20 March 2020). 